Invited paper

\title{
Using nitrogen concentration and isotopic composition in lichens to spatially assess the relative contribution of atmospheric nitrogen sources in complex landscapes ${ }^{2 / 2}$
}

\author{
P. Pinho ${ }^{\text {a, b, * }, ~ C . ~ B a r r o s ~}{ }^{\text {a, c, d }}$, S. Augusto ${ }^{a,}$,, M.J. Pereira ${ }^{b}$, C. Máguas ${ }^{a}$, C. Branquinho ${ }^{a}$ \\ ${ }^{a}$ Centre for Ecology, Evolution and Environmental Changes, Faculdade de Ciências, Universidade de Lisboa (CE3C-FC-ULisboa), Edifício C2, $5^{\circ}$ piso, Campo \\ Grande, 1749-016 Lisboa, Portugal \\ ${ }^{\mathrm{b}}$ Centro de Recursos Naturais e Ambiente, Instituto Superior Técnico, Universidade de Lisboa (CERENA-Técnico/ULisboa), Av. Rovisco Pais, 1049-001 Lisboa, \\ Portugal \\ ${ }^{c}$ Laboratoire d'Écologie Alpine (LECA), Université Grenoble Alpes, F-38000 Grenoble, France \\ d Laboratoire d'Écologie Alpine (LECA), CNRS, F-38000 Grenoble, France \\ e ISPUP-EPIUnit, Universidade do Porto, Rua das Taipas, $n^{\circ} 135$, 4050-600 Porto, Portugal
}

\section{A R T I C L E I N F O}

\section{Article history:}

Received 31 October 2016

Received in revised form

22 June 2017

Accepted 29 June 2017

Available online 13 July 2017

\section{Keywords:}

Reactive nitrogen

Eutrophication

Isoscapes

Multiple pollution sources

\begin{abstract}
A B S T R A C T
Reactive nitrogen $(\mathrm{Nr})$ is an important driver of global change, causing alterations in ecosystem biodiversity and functionality. Environmental assessments require monitoring the emission and deposition of both the amount and types of $\mathrm{Nr}$. This is especially important in heterogeneous landscapes, as different land-cover types emit particular forms of $\mathrm{Nr}$ to the atmosphere, which can impact ecosystems distinctively. Such assessments require high spatial resolution maps that also integrate temporal variations, and can only be feasibly achieved by using ecological indicators. Our aim was to rank land-cover types according to the amount and form of emitted atmospheric $\mathrm{Nr}$ in a complex landscape with multiple sources of $\mathrm{N}$. To do so, we measured and mapped nitrogen concentration and isotopic composition in lichen thalli, which we then related to land-cover data. Results suggested that, at the landscape scale, intensive agriculture and urban areas were the most important sources of $\mathrm{Nr}$ to the atmosphere. Additionally, the ocean greatly influences $\mathrm{Nr}$ in land, by providing air with low $\mathrm{Nr}$ concentration and a unique isotopic composition. These results have important consequences for managing air pollution at the regional level, as they provide critical information for modeling $\mathrm{Nr}$ emission and deposition across regional as well as continental scales.
\end{abstract}

() 2017 Elsevier Ltd. All rights reserved.

\section{Introduction}

Reactive nitrogen $(\mathrm{Nr})$ includes all nitrogen forms capable of readily reacting and causing a number of cascading effects in the environment: reduced nitrogen as ammonia and ammonium $\left(\mathrm{NH}_{3}\right.$ and $\left.\mathrm{NH}_{4}\right)$, oxidized nitrogen oxides $\left(\mathrm{NO}_{\mathrm{x}}\right)$, nitrous oxide $\left(\mathrm{N}_{2} \mathrm{O}\right)$, nitrate $\left(\mathrm{NO}_{3}{ }^{-}\right)$and nitrite $\left(\mathrm{NO}_{2}^{-}\right)$. Reactive nitrogen is released from human activities and its levels already exceed those of naturally fixed $\mathrm{N}$ forms. This excess has negative impacts on ecosystem structure and functionality (Erisman et al., 2007; van den Berg et al.,

\footnotetext{
This paper has been recommended for acceptance by Dr. Hageman Kimberly Jill.

* Corresponding author. CERENA- Centro de Recursos Naturais e Ambiente, Instituto Superior Técnico, Av. Rovisco Pais, 1049-001 Lisboa, Portugal.

E-mail address: ppinho@fc.ul.pt (P. Pinho).
}

2016). Knowing where excessive $\mathrm{Nr}$ is being deposited is important in order to take appropriate management actions. However, mapping $\mathrm{Nr}$ deposition is not trivial (Hertel et al., 2012). On the one hand, $\mathrm{Nr}$ has multiple sources that can be diffuse (such as agriculture or urban areas) or point sources (such as barns or chimneys). These different $\mathrm{Nr}$ sources co-occur with other areas that emit little or no $\mathrm{Nr}$ (such as forests) - $\mathrm{Nr}$ sinks. On the other hand, some $\mathrm{Nr}$ forms such as atmospheric ammonia $\left(\mathrm{NH}_{3}\right)$ have a short dispersion range (albeit large impacts on biological systems; Sutton et al., 1998; Pinho et al., 2011), generating high spatial heterogeneity in $\mathrm{Nr}$ deposition (Pinho et al., 2014a). Using monitoring stations to map $\mathrm{Nr}$ deposition is very costly due to the large number of stations required to capture the spatial heterogeneity of $\mathrm{Nr}$ sources. Conversely, using passive samplers is not practicable, as they need to be frequently replaced to allow for temporal integration. To overcome these issues, modeling approaches have provided 
spatially explicit estimations of $\mathrm{Nr}$ deposition. Yet, so far these models have been bounded to mapping very small areas with one or few sources of $\mathrm{Nr}$ at high resolutions or to mapping large regions at very coarse spatial resolutions (EEA, 2007). Moreover, modeling $\mathrm{Nr}$ deposition requires knowing all sources, which is not feasible in large regions where multiple sources and sinks coexist, and have different and unknown relative strengths. This is the case in European Mediterranean landscapes, where different land-cover types co-occur at relatively small spatial scales and act as distinct $\mathrm{Nr}$ sources or sinks.

Lichens can be used as ecological indicators of $\mathrm{Nr}$ deposition, providing an excellent tool to overcome the issues of spatial resolution (Ribeiro et al., 2014) and temporal integration stated above. Lichens are the result of a symbiosis between algae and fungi and both lichen diversity (Giordani, 2007; Pinho et al., 2004, 2008a, $2008 \mathrm{~b}$ ) and lichen accumulation of pollutants (Augusto et al., 2010; Branquinho et al., 2008) are indicators of atmospheric pollution. In particular, lichens can be used as indicators of $\mathrm{Nr}$ concentration (Olsen et al., 2010), as $\mathrm{Nr}$ concentration in lichens reflects the amount of $\mathrm{Nr}$ deposition from the atmosphere (Liu et al., 2008; Pinho et al., 2014b; Zechmeister et al., 2008). In fact, repeated sampling of a species in a given area with a single $\mathrm{Nr}$ source has shown that lichen $\mathrm{Nr}$ concentration (N\%) reflects $\mathrm{Nr}$ deposition in that area (Branquinho et al., 2010; Gaio-Oliveira et al. 2001, 2005).

Yet, multiple sources of $\mathrm{Nr}$ are likely to co-occur at larger spatial scales, and emit distinct forms and amounts of $\mathrm{Nr}$, such as reduced $\left(\mathrm{NH}_{\mathrm{y}}\right)$ and oxidized $\left(\mathrm{NO}_{\mathrm{x}}\right)$ nitrogen (Boltersdorf and Werner, 2013). Identifying the possible sources of pollutants, i.e. sourceapportionment, is thus essential for mapping $\mathrm{Nr}$ deposition at large spatial scales without losing resolution. This can be achieved by analyzing nitrogen isotopic composition $\left(\delta^{15} \mathrm{~N}\right)$ of the emitted pollutant, as different $\mathrm{Nr}$ forms carry a different isotopic signal, i.e. more or less depleted in the heavier isotope $\left({ }^{15} \mathrm{~N}\right.$; Felix and Elliott, 2014; Felix et al., 2014). Source apportionment using stable isotopes is usually done with mixing models (Phillips and Gregg, 2003). However, this is a complex approach and becomes impractical when many different sources are present. This is impractical because to run such models requires knowing the isotopic composition of all sources of $\mathrm{Nr}$ in the area. However not all sources are known a priori, and in large areas this can never be achieved. To overcome this problem, $\mathrm{Nr}$ deposition in ecosystems can be used as a nitrogen deposition mapping tool. Plants have been shown to respond to different $\mathrm{Nr}$ sources by displaying different isotopic composition (Hellmann et al., 2016); yet, they exhibit a limited range of isotopic composition values (although larger variations exist when nitrogen uptake is mainly foliar; see Fogel et al., 2008). Unlike vascular plants, lichens and bryophytes exibit a large variation in nitrogen isotopic composition, and for a given area $\delta^{15} \mathrm{~N}$ values are more negative than those for vascular plants (Fogel et al., 2008). Importantly, $\mathrm{N}$ isotopic composition in lichens and bryophites has been shown to be related to surrounding $\mathrm{Nr}$ sources. For instance, $\delta^{15} \mathrm{~N}$ values of lichens and bryophytes collected in agricultural areas tend to be more negative, while those located in areas without important $\mathrm{Nr}$ sources tend to be more positive (Boltersdorf and Werner, 2013; Varela et al., 2013). Moreover, lichens should reflect closely the ${ }^{15} \mathrm{~N} /{ }^{14} \mathrm{~N}$ ratio of the atmosphere, even under rather depleted atmospheric values ( -19\%; Fogel et al., 2008). However, the characteristic $\mathrm{N} \%$ and isotopic composition $\left(\delta^{15} \mathrm{~N}\right)$ of each land-cover type remain poorly characterized in lichens, especially in areas with multiple sources. Thus, we confidently assume that the (relative) $\delta^{15} \mathrm{~N}$ measured in lichens along an environmental gradient of $\mathrm{Nr}$ sources reflects the relative composition of the main $\mathrm{Nr}$ sources in that area.

Here we aimed to support the use of $\mathrm{Nr}$ emission/deposition models, by using lichens as ecological indicators to rank land-cover types according to the amount and form of emitted atmospheric $\mathrm{Nr}$. To demonstrate the potential of this approach we chose a complex study area with multiple $\mathrm{Nr}$ sources, including industries and agriculture, for each of which we identified the typical isotopic signature. This information can be used in $\mathrm{Nr}$ emission/deposition models to account for the form and amount of nitrogen emitted by each land-cover type, therefore having important implications for air pollution management at the regional level.

\section{Methods}

\subsection{Study area and sampling design}

This study covers a coastal area in southwest Europe of c. $380 \mathrm{~km}^{2}$ (Portugal, Alentejo Litoral region). Climate in this region is typically Mediterranean, with average annual temperatures ranging from $15.7^{\circ} \mathrm{C}$ to $17.1^{\circ} \mathrm{C}$ and a total annual precipitation of $\mathrm{c}$. $600 \mathrm{~mm}$ (1950-2000 average) (Hijmans et al., 2005). The area hosts a population of c. 34565 inhabitants (INE, 2011) and important industrial facilities (in Sines) that include petrochemical industries, an oil refinery, an industrial harbor, a coal-fueled power plant and an industrial water treatment plant. Apart from the industrial facilities, there are also three cities and many smaller settlements in a matrix of forested areas (including cork oak woodlands and pine and eucalyptus plantations) and shrubland. Agriculture can be found in the remaining areas, including orchards and small-scale animal farms, but these areas are mainly constituted by non-irrigated extensive agriculture for grain cultivation and irrigated high-intensity agriculture for vegetables and rice, most of which heavily fertilized (Fig. 1).

Sampling was distributed evenly across the study area in 43 sampling points (average distance between points $2300 \mathrm{~m}$, $\max =4900 \mathrm{~m}, \min =650 \mathrm{~m}$ ), where in situ thali of Parmotrema hypoleucinum (Steiner) Hale were collected for analysis. By collecting in-situ lichens we ensured that the samples had been exposed to $\mathrm{Nr}$ deposition for a long period, thus representing a temporal integration of $\mathrm{Nr}$ deposition. We selected $P$. hypoleucinum because it can be found abundantly across this region due to its mild tolerance to a range of disturbances. It is a green algae species only, thus not know to be able to fix $\mathrm{Nr}$ from atmospheric $\mathrm{N}_{2}$. Lichen samples were collected in a single day on February 7th, 2011. To ensure that the conditions were adequate for $\mathrm{Nr}$ volatilization from agriculture, we verified weather data of the period prior to the sampling date (from November 1st, 2010 to February 7th, 2011) from the nearest official climate monitoring station (IPMA). During this 99-day period there were 56 days without precipitation, which ensured both that the soil was wet enough for $\mathrm{Nr}$ volatilization, but also that there were no barriers for $\mathrm{Nr}$ dispersion. Also during this period, there were a total of 65 days with a temperature above $15^{\circ} \mathrm{C}$, which also ensures $\mathrm{Nr}$ volatilization from agriculture fields. One $10 \mathrm{~g}$ composite sample was collected from 1 to 5 trees (using the available tree species - mostly pines and cork oaks). Lichens were collected from at least $1 \mathrm{~m}$ from the ground (to ensure a prevalent effect of atmospheric conditions, rather than an influence of the soil) and only from living trees.

Lichen samples were cleaned from debris, dried at room temperature and powdered in a Reitsch MM2000 ball-mill. Stable isotope ratio analyses were performed at the Stable Isotopes and Instrumental Analysis Facility (SIIAF), at the Faculdade de Ciências, Universidade de Lisboa - Portugal. Sample isotopic composition, $\delta^{15} \mathrm{~N}$, was determined by continuous flow isotope mass spectrometry (CF-IRMS) (Preston and Owens, 1983), on a Sercon Hydra 20-22 (Sercon, UK) stable isotope ratio mass spectrometer, coupled to a EuroEA (EuroVector, Italy) elemental analyser for 


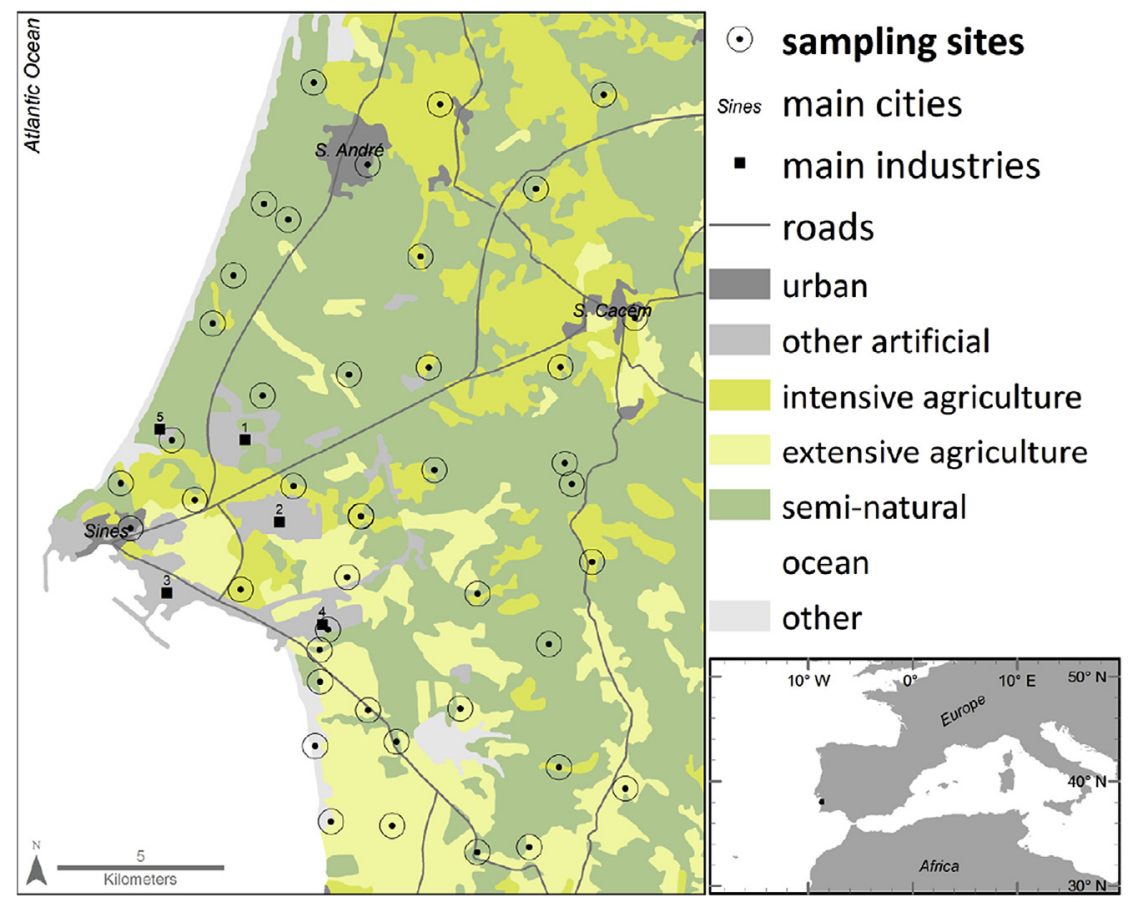

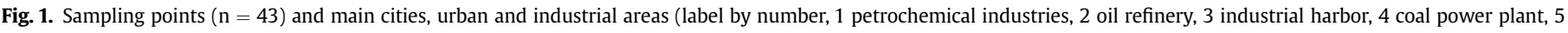
industrial water treatment plant), and land cover adapted from Corine Land Cover (Caetano et al., 2009).

online sample preparation by Dumas-combustion. Delta calculation was performed according to $\delta=\left[\left(\mathrm{R}_{\text {sample }}-\mathrm{R}_{\text {standard }}\right) / \mathrm{R}_{\text {standard }}\right]$, where $\mathrm{R}$ is the ${ }^{15} \mathrm{~N} /{ }^{14} \mathrm{~N}$ ratio. $\delta^{15} \mathrm{~N}_{\text {Air }}$ values are referred to air. The (secondary) reference materials used were Sorghum Flour Standard OAS and Wheat Flour Standard OAS (Elemental Microanalysis, UK) for nitrogen (with, respectively, $\delta^{15} \mathrm{~N}_{\text {Air }}$ (Sorghum Flour $\mathrm{OAS})=1.58 \pm 0.15 \%$ and $\delta^{15} \mathrm{~N}_{\text {Air }}$ (Wheat Flour OAS $)=2.85 \pm 0.17 \% 0$ ). These were regularly checked against primary reference materials IAEA-N1, USGS-35, IAEA-600 and IAEA-CH7 (Coleman and MeierAugenstein, 2014). The uncertainty of the isotope ratio analysis was calculated using values from 6 to 9 replicates of secondary isotopic reference material interspersed among samples in every batch analysis, and resulted in $\leq 0.1 \%$. The major mass signals of $\mathrm{N}$ were used to calculate total $\mathrm{N}$ abundance using two elemental composition reference materials, Sorghum Flour Standard OAS and Wheat Flour Standard OAS (Elemental Microanalysis, UK) with $1.47 \% \mathrm{~N}$ and $1.47 \% \mathrm{~N}$, respectively.

\subsection{Data analysis}

The $\mathrm{N} \%$ and $\delta{ }^{15} \mathrm{~N}$ data were firstly interpolated within the study area for visual interpretation. Interpolation was done using ordinary kriging after manual fitting of a function to the experimental variogram (Goovaerts, 1997). A single spherical isotropic function fit well all analyzed variables and thus was used for the interpolations.

To determine the main sources of $\mathrm{Nr}$ in the study area, we calculated univariate non-parametric correlations (Spearman) between $\mathrm{N} \%$ and $\delta^{15} \mathrm{~N}$ and the area occupied by surrounding landcover types, in order to account for monotonic non-linear relationships. As a first step, all level III classes of Corine Land Cover were considered (Caetano et al., 2009) (see S. Table 1). We merged Corine classes by level (considering level I, e.g. all classes belonging to class "agriculture") and by their relationship with lichenvariables (either significantly positive/negative, or non-significant relationships; Table 1). Further analyses were done on these merged classes. To calculate the area occupied by surrounding land cover we considered several buffers around sampling sites, using circular shapes with radius sizes ranging from 80 to $5120 \mathrm{~m}(80$, $160,320,640,1280,2560,5120 \mathrm{~m}$ ). Larger radii were not used as they included most of the study area, resulting in meaningless correlation values. All radius sizes were tested (data not shown). Since the largest radius $(5120 \mathrm{~m})$ resulted in the most significant correlations between $\mathrm{N} \%$ and $\delta^{15} \mathrm{~N}$ variables and most land-cover types, it was the only radius size retained for further analyses.

Typical $\mathrm{N} \%$ and $\delta^{15} \mathrm{~N}$ land-cover values were analyzed for the land-cover types that most influenced $\mathrm{Nr}$ variables (according to the univariate correlations described above). To do so, we subset 5 unique sampling points per selected land-cover variable: that is, we retrieved the top 5 sampling points with the largest coverage of each land-cover type (considering the $5120 \mathrm{~m}$ radius), while ensuring that no given point was simultaneously selected for more than one land-cover type. Considering these points, boxplots of N\% and $\delta^{15} \mathrm{~N}$ were drawn to show the typical expected values of $\mathrm{N} \%$ and $\delta^{15} \mathrm{~N}$ for each land-cover type.

Spatial analyses were carried out using ArcGis v.10 (ESRI, 2010) and GeoMs (CERENA, 2000). Other statistical analyses were performed using CRAN software $R$ (R Core Team, 2013) and Statistica $v .10$ (Statsoft, 2012). Significance level $\alpha$ was set at 0.05 .

\section{Results}

Values of $\mathrm{N} \%$ in lichens ranged from $0.79 \%$ to $1.89 \%$ and $\delta^{15} \mathrm{~N}$ was always negative, from $-6.76 \%$ to $-15.59 \%$ (see Fig. 2 for summary statistics). Variogram analysis of $\mathrm{N} \%$ revealed a strong spatial structure at short distances with a nugget/total variance $=0.3$ and $2000 \mathrm{~m}$ range. $\delta^{15} \mathrm{~N}$ revealed a stronger spatial structure and at larger distances, with no nugget effect and a $6000 \mathrm{~m}$ range. Interpolation of the variables revealed their spatial patterns (Fig. 2). Higher N\% were found to the northeast and southwest of the study area and lower N\% were located mostly near the ocean, except near Sines's industrial area. Values of $\delta^{15} \mathrm{~N}$ were more negative to the 
Table 1

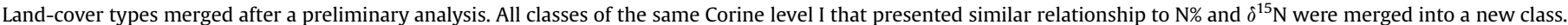

\begin{tabular}{|c|c|c|}
\hline original Corine class number & land-cover class in this work & description of the land-cover class \\
\hline 111 to 112 & urban & mostly low-density urban areas \\
\hline 121 to 142 & other artificial & mostly industrial areas and roads \\
\hline 212 to 244 & intensive agriculture & irrigated and fertilized agriculture (rice and vegetable fields), small orchards and farms \\
\hline 211 & extensive agriculture & non-irrigated agriculture mostly for grain \\
\hline 311 to 324 & semi-natural & pine plantations (sea-side) and cork oak woodlands (inland) and also some dunes and scrubs \\
\hline 523 & ocean & open ocean areas \\
\hline 411 to 522 & other & inland and brackish waters (very uncommon and not considered in the analyses) \\
\hline
\end{tabular}

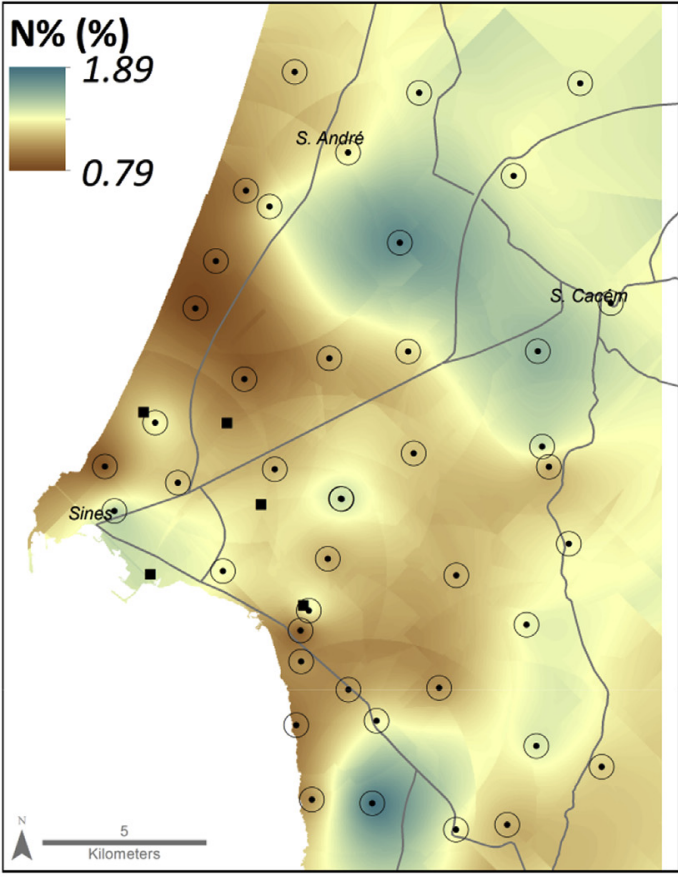

$\odot$ sampling sites sines main cities

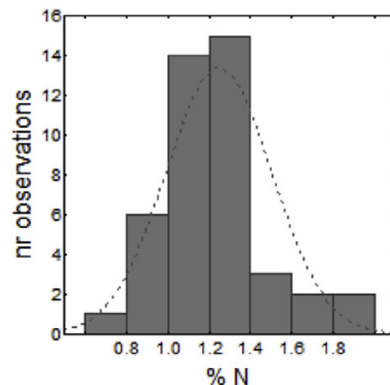

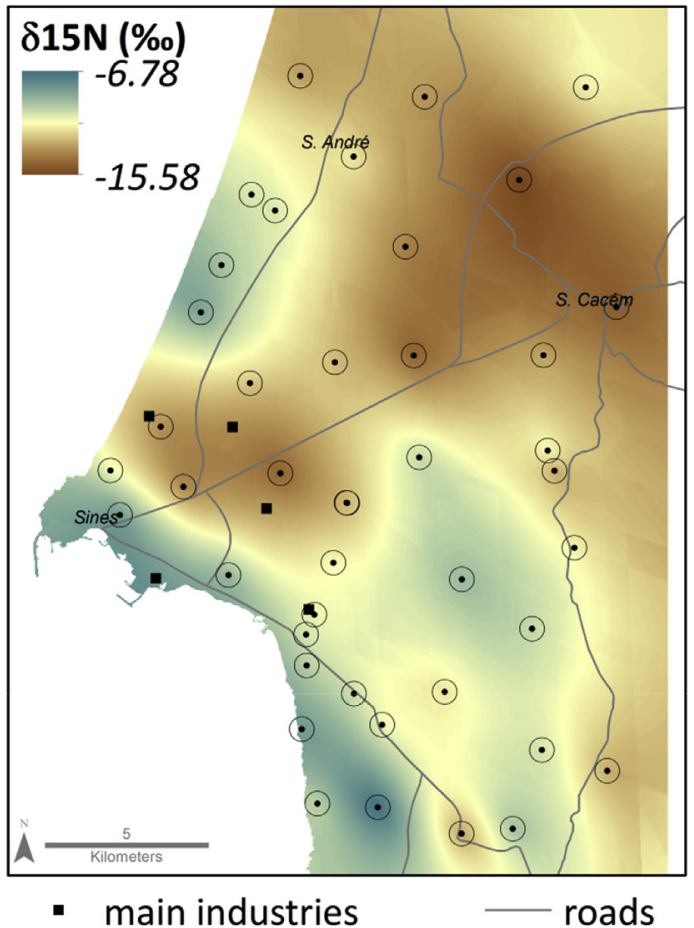

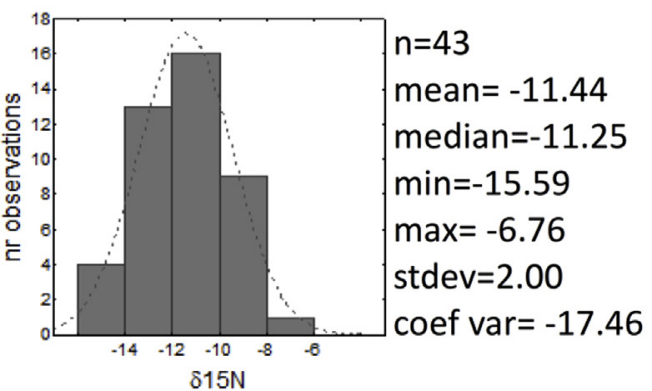

Fig. 2. Interpolated maps of $\mathrm{N} \%$ (in \%) and $\delta^{15} \mathrm{~N}$ (in \%o) measured in lichens and summary statistics for their observed values.

northeast of the study area and less negative near the coast, except to the north of Sines's industrial area.

Univariate correlations showed N\% was significantly and positively correlated to urban areas and intensive agriculture areas, and negatively so with ocean areas (Table 2). No significant correlations were found for industrial areas or roads, grouped under the other artificial class. Values of $\delta^{15} \mathrm{~N}$ showed significant positive correlations with extensive agriculture and ocean, and negative correlations with urban, intensive agriculture and semi-natural areas. Both for $\mathrm{N} \%$ and $\delta^{15} \mathrm{~N}$, the most significant correlations were found with areas occupied by intensive agriculture.

The univariate correlation analysis suggested that ocean, urban and intensive agriculture were the main drivers of $\mathrm{Nr}$ deposition, hence typical values of $\mathrm{N} \%$ and $\delta^{15} \mathrm{~N}$ were plotted for these landcover types (Fig. 3). Points under great oceanic influence showed the lowest $\mathrm{N} \%$ (median $=0.87 \%, \max =1.05 \%$, $\min =0.79 \%$, stdev $=0.10$ ) and the least negative $\delta^{15} \mathrm{~N}$ (median $=-9.43 \%$, $\max =-8.27 \%$, $\min =-10.95 \%$, stdev $=1.10 \%$ ). In opposition, points under more influence from intensive agriculture showed the highest $\mathrm{N} \%$ (median $=1.39 \%, \max =1.61 \%, \min =1.36 \%$, stdev $=0.10 \%$ ) and the more negative $\delta^{15} \mathrm{~N}$ values (median $=-13.04 \%$, $\max =-11.24 \%$, $\min =-15.59 \%$, stdev $=1.96 \%$ ). The points more influenced by urban areas showed intermediate values of both $\mathrm{N} \%$ (median $=1.29 \%$, $\max =1.46 \%$, 
Table 2

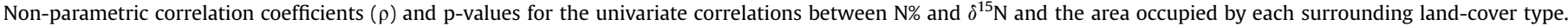
Significant correlations are shown in bold ( $\mathrm{p}$-value $<0.05$ ). $\mathrm{N}=43$.

\begin{tabular}{|c|c|c|c|c|c|c|c|}
\hline & & urban & other artificial & extensive agriculture & intensive agriculture & semi-natural & ocean \\
\hline \multirow[t]{2}{*}{$\mathrm{N} \%$} & $\rho$ & 0.31 & -0.23 & -0.06 & 0.44 & 0.25 & -0.44 \\
\hline & p-value & 0.046 & 0.143 & 0.715 & 0.003 & 0.102 & 0.003 \\
\hline \multirow[t]{2}{*}{$\delta^{15} \mathrm{~N}$} & $\rho$ & -0.33 & 0.13 & 0.34 & -0.69 & -0.32 & 0.43 \\
\hline & p-value & 0.0302 & 0.389 & 0.027 & 0.000 & 0.036 & 0.004 \\
\hline
\end{tabular}

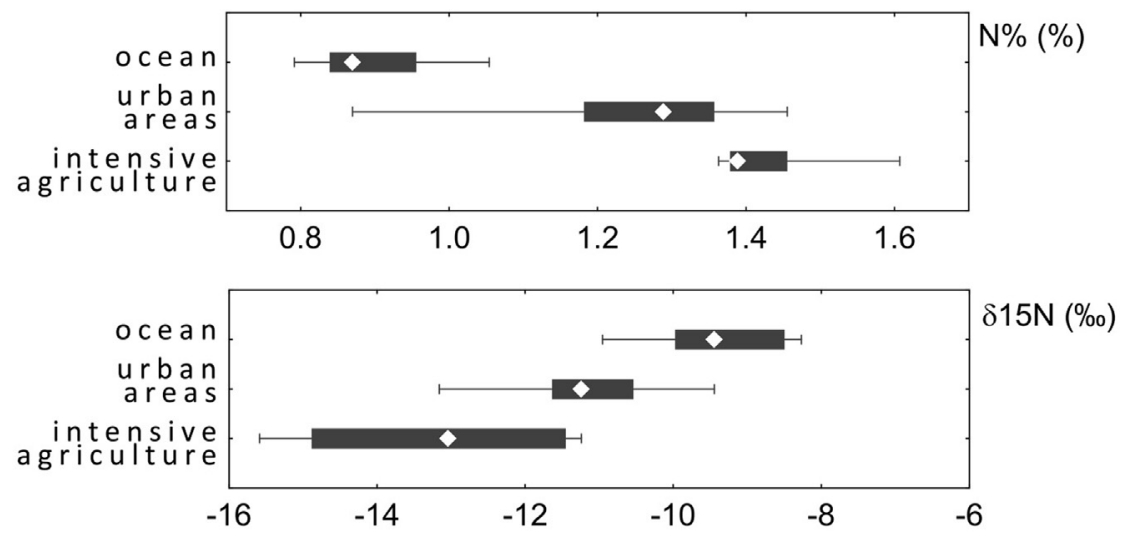

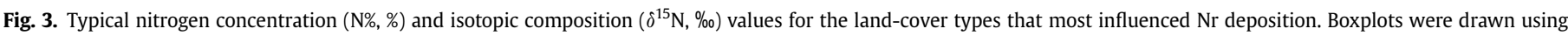

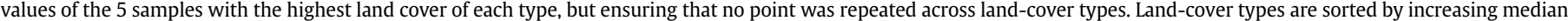
$\delta^{15} \mathrm{~N}$. The median, 0.25 and 0.75 percentiles (boxes) and the minimum and maximum (whiskers) are shown.

$\min =0.87$, stdev $=0.22 \%$ ) and $\delta^{15} \mathrm{~N}$ (median $=-11.24 \%$, $\max =-9.44 \%$ o, $\min =-13.16 \%$, stdev $=1.37 \%$ o).

\section{Discussion}

Our study has shown that intensive agriculture, urban areas and the ocean can have important, but distinct, influences on $\mathrm{Nr}$ deposition at the landscape scale, generating spatially heterogeneous patterns. While intensive agriculture and urban areas were associated with higher $\mathrm{N} \%$ and more negative $\delta^{15} \mathrm{~N}$ values, samples from areas dominated by ocean influence had lower N\% and more positive $\delta^{15} \mathrm{~N}$.

The positive relationship between nitrogen concentration and surrounding land cover suggested that the most important sources of $\mathrm{Nr}$ deposition in our study area are intensive agriculture and, albeit less importantly, urban areas. Agricultural activities are known to be the most important human source of $\mathrm{Nr}-$ mostly in the form of reduced $\mathrm{Nr}\left(\mathrm{NH}_{\mathrm{y}}\right)$ (Erisman et al., 2008), but also oxidized $\mathrm{Nr}$ (Felix and Elliott, 2014) - and lichens have been shown to accumulate nitrogen when growing near agricultural areas (Boltersdorf and Werner, 2013). Urban areas have also been associated with the emission of $\mathrm{Nr}$ compounds, both in their reduced (e.g. from sewage treatment plants; Liu et al., 2008) and oxidized $\left(\mathrm{NO}_{\mathrm{x}}\right.$, e.g. from industries and vehicles combustions) forms, the latter being dominant. Yet, in order to distinguish between these potential $\mathrm{Nr}$ sources we considered $\mathrm{Nr}$ isotopic composition. Other authors analyzing isotopic composition of atmospheric nitrogen showed more negative values of $\delta^{15} \mathrm{~N}$ for reduced nitrogen than for oxidized nitrogen. For example, atmospheric ammonia emitted by cattle ranged from -56 to $-23 \% 0 \delta^{15} \mathrm{~N}$ values (Felix et al., 2013) and atmospheric ammonia derived from the application of fertilizers ranged from -48 to $-25.6 \% \delta^{15} \mathrm{~N}$. Correspondingly, $\delta^{15} \mathrm{~N}$ values for lichens collected in Germany from areas with high cattle density ranged from -10 to $-8 \%$ (Boltersdorf and Werner, 2014). However,
Crittenden et al. (2015) showed completely different values for lichens close to a penguin rookery in Antarctica, ranging from -0.9 and $+9.0 \%$. Also, $\delta^{15} \mathrm{~N}$ values of ammonia emitted by industries $(-15$ to $+2 \%$ ) or vehicles ( -5 to $-3 \%$ ) generally tend to be higher than ammonia emitted by agricultural activities (Felix et al., 2013). On the other hand, $\delta^{15} \mathrm{~N}$ values for $\mathrm{NO}_{\mathrm{x}}$ range from +5 to $+10 \%$ o (with a maximum of $+15 \%$ ) when emitted from traffic (Felix and Elliott, 2014; Laffray et al., 2010), +10 to $+25 \%$ from power plants (Felix et al., 2012), -8.5 to $-29 \%$ from cattle waste and -26.5 to $-30.8 \%$ from fertilized soil. In our study area, the rather negative $\delta^{15} \mathrm{~N}$ values and high $\mathrm{N} \%$ observed in lichens collected under the influence of intensive agriculture (median $=1.39 \%$, and median $=-13.04 \%$ ) suggested that the main source of $\mathrm{Nr}$ emitted by human activities, and then captured by lichens, derived from agriculture in the form of reduced nitrogen, i.e. $\mathrm{NH}_{\mathrm{x}}$. The presence of an area with low $\delta^{15} \mathrm{~N}$ values near the industrial area suggested, by visual interpretation, that some $\mathrm{Nr}$ volatized by the industrial facilities (e.g. the industrial sewage treatment plant) is being incorporated into lichens (Fig. 2). However, this is likely occurring at very low amounts, not modifying the nitrogen-concentration measured in lichens at the regional scale.

We observed a general lack of agreement between the presence of artificial areas other than urban ("other artificial areas", including roads and industrial facilities) and nitrogen concentrations and $\delta^{15} \mathrm{~N}$ values. Since $\mathrm{NO}_{\mathrm{x}}$ has a much higher dispersion range than reduced nitrogen (see Fournier et al., 2004), this lack of agreement may be caused by the deposition of this oxidized nitrogen far from its sources, possibly outside the sampling area. To test for this, we would need to assess the relationship between atmospheric $\mathrm{NO}_{\mathrm{x}}$ concentration and nitrogen variables in lichens, or to extend our study to a much larger area. Additionally, fungal cell walls are predominately negatively charged, which may prevent the entrance of the negatively charged oxidized nitrogen $\left(\mathrm{NO}_{3}^{-}\right)$and favor the entrance of the positively charged reduced nitrogen 
$\left(\mathrm{NH}_{4}^{+}\right)$, thus masking relationships between atmospheric $\mathrm{NO}_{\mathrm{x}}$ and $\mathrm{N}$ $\%$ and $\delta^{15} \mathrm{~N}$ values in lichens.

In the study area, the oceanic influence is expected to be rather strong inland due the prevailing winds from north-north west. In fact, the spatial pattern of N\% in lichens has showed the lowest values near the coast, supporting the idea that terrestrial ecosystems have a prevailing role in processing $\mathrm{Nr}$ (Fowler et al., 2013). Moreover, more positive $\delta^{15} \mathrm{~N}$ values were observed near the coast, which suggests a very different isotopic signature from that of inland $\mathrm{Nr}$ sources found in other studies (Lin et al., 2016). Ocean ammonia was shown to have nearly positive $\delta^{15} \mathrm{~N}$ values $(-10$ to $-2 \%$, Felix et al., 2013) or even completely positive if the analyzed ammonia comes from remote sources $(0$ to $+6 \%$, Lin et al., 2016). We were able to detect this distinct atmospheric $\mathrm{Nr}$ isotopic signal, which has also been shown in vegetation growing under a strong sea influence. Indeed, lichens in Antarctica that were largely influenced by the ocean breeze displayed higher $\delta^{15} \mathrm{~N}$ values (close to zero) than those located inland (Il Lee et al., 2009). These results support our interpretation that ocean provides air with low $\mathrm{Nr}$ concentrations and a different isotopic composition from inland air. By visual interpretation of the $\delta^{15} \mathrm{~N}$, we estimate that this influence is more important within the first $3 \mathrm{~km}$ of the coast, which is in agreement with other studies that measured salt deposition in the same region (Figueira et al., 1999).

Knowing in a regional area which land-cover emits more or less $\mathrm{Nr}$ and its form is important to local air quality plans, because the amount and form of $\mathrm{Nr}$ can have different impacts on ecosystems. Hence, our results and study approach can be of great use in analyses that attempt to model nitrogen emission and deposition from local to regional spatial scales. Models such as FRAME (Fournier et al., 2004) or EMEP (European Monitoring and Evaluation Programme) rely on attributing a value of $\mathrm{Nr}$ emissions to each landcover type, especially for poorly characterized diffuse sources. However, not all areas with the same land-cover type emit the same amounts, e.g. one agriculture area can be more heavily fertilized than other. Being able to rank the different areas can thus improve model output accuracy. These results can also be used to test predictions by these and other types of models, such as mixing models used to estimate source proportions. While the values found in lichens may not be directly comparable to the ones predicted by the models, the relative proportions modeled across environmental gradients (e.g. regarding more agricultural versus oceanic sources) should match the relative values found in lichens across the same environmental gradient. If not, then there is likely a source not being accounted for in the model, and that source should then be added, or further investigated.

\section{Conclusion}

We used lichens to rank land-cover types according to the amount and form of emitted atmospheric $\mathrm{Nr}$, in a large region with multiple $\mathrm{Nr}$ sources. We observed that areas dominated by agricultural sources emitted large amounts of $\mathrm{Nr}$ with very negative $\delta^{15} \mathrm{~N}$ values, possibly in the form of reduced $\mathrm{N}$. Urban areas were also a source of $\mathrm{Nr}$ with negative $\delta^{15} \mathrm{~N}$ values, but to a lesser extent. The ocean had a large impact on both the amount and form of $\mathrm{Nr}$, because it was a source of air with low $\mathrm{Nr}$ concentrations and more positive $\delta^{15} \mathrm{~N}$ values. Analyzing nitrogen concentration and isotopic values in lichens can thus provide valuable information on the form and amount of atmospheric $\mathrm{Nr}$ emitted by distinct land-cover types. This information can be extremely valuable for modeling atmospheric $\mathrm{Nr}$ emission/deposition in large regions and to estimate how each source impacts ecosystems, thus having important consequences for managing atmospheric pollution at regional scales.

\section{Acknowledgments}

Supported by project GISA (funded by private companies: GALP, Repsol, APS, AdSA, AICEP, CARBOGAL, EDP, EuroResinas, KIMAXTRA, REN and GENERG; and managed by local authorities: CCDRA, ARSA and Municipalities of Sines, Santiago do Cacém, Grândola, Álcacer do Sal and Odemira. Further support for researchers from FCTMCTES (SFRH/BPD/75425/2010, SFRH/BPD/109382/2015 and Investigador FCT contract) and EC-H2020 (NitroPortugal 692331).

\section{Appendix A. Supplementary data}

Supplementary data related to this article can be found at http:// dx.doi.org/10.1016/j.envpol.2017.06.102.

\section{References}

Augusto, S., Maguas, C., Matos, J., Pereira, M.J., Branquinho, C., 2010. Lichens as an integrating tool for monitoring $\mathrm{PAH}$ atmospheric deposition: a comparison with soil, air and pine needles. Environ. Pollut. 158, 483-489.

Boltersdorf, S., Werner, W., 2013. Source attribution of agriculture-related deposition by using total nitrogen and $\mathrm{N}-15$ in epiphytic lichen tissue, bark and deposition water samples in Germany. Isotopes Environ. Health Stud. 49, 197-218.

Boltersdorf, S.H., Werner, W., 2014. Lichens as a useful mapping tool?-an approach to assess atmospheric $\mathrm{N}$ loads in Germany by total $\mathrm{N}$ content and stable isotope signature. Environ. Monit. Assess. 186, 4767-4778.

Branquinho, C., Gaio-Oliveira, G., Augusto, S., Pinho, P., Maguas, C., Correia, O., 2008. Biomonitoring spatial and temporal impact of atmospheric dust from a cement industry. Environ. Pollut. 151, 292-299.

Branquinho, C., Pinho, P., Dias, T., Cruz, C., Máguas, C., Martins-Loução, M.A., 2010. Lichen transplants at our service for atmospheric $\mathrm{NH}_{3}$ deposition assessments. Bibl. Lichenol. 105, 103-112.

Caetano, M., Nunes, V., Nunes, A., 2009. CORINE Land Cover 2006 for Continental Technical Report. Instituto Geográfico Português, p. 81.

CERENA, 2000. Centre for Natural Resources and the Environment, GeoMs - Geostatistical Modelling Software.

Crittenden, P.D., Scrimgeour, C.M., Minnullina, G., Sutton, M.A., Tang, Y.S., Theobald, M.R., 2015. Lichen response to ammonia deposition defines the footprint of a penguin rookery. Biogeochemistry 122, 295-311.

Coleman, M., Meier-Augenstein, W., 2014. Ignoring IUPAC guidelines for measurement and reporting of stable isotope abundance values affects us all. Rapid Commun. Mass Spectrom. 28, 1953-1955.

EEA, 2007. EMEP/CORINAIR Emission Inventory Guidebook. Copenhagen.

Erisman, J.W., Bleeker, A., Galloway, J., Sutton, M.S., 2007. Reduced nitrogen in ecology and the environment. Environ. Pollut. 150, 140-149.

Erisman, J.W., Sutton, M.A., Galloway, J., Klimont, Z., Winiwarter, W., 2008. How a century of ammonia synthesis changed the world. Nat. Geosci. 1, 636-639.

ESRI, 2010. ArcMap V. 10.0.

Felix, J.D., Elliott, E.M., Gish, T., Maghirang, R., Cambal, L., Clougherty, J., 2014. Examining the transport of ammonia emissions across landscapes using nitrogen isotope ratios. Atmos. Environ. 95, 563-570.

Felix, J.D., Elliott, E.M., Gish, T.J., McConnell, L.L., Shaw, S.L., 2013. Characterizing the isotopic composition of atmospheric ammonia emission sources using passive samplers and a combined oxidation-bacterial denitrifier approach. Rapid Commun. Mass Spectrom. 27, 2239-2246.

Felix, J.D., Elliott, E.M., Shaw, S.L., 2012. Nitrogen isotopic composition of coal-fired power plant NOx: influence of emission controls and implications for global emission inventories. Environ. Sci. Technol. 46, 3528-3535.

Figueira, R., Sousa, A.J., Pacheco, A.M.G., Catarino, F., 1999. Saline variability at ground level after kriging data from Ramalina spp. biomonitors. Sci. Total Environ. 232, 3-11.

Fogel, M.L., Wooller, MJ. Cheeseman, J., Smallwood, B.J., Roberts, Q., Romero, I. Meyers, M.J., 2008. Unusually negative nitrogen isotopic compositions $(\operatorname{delta}(15) \mathrm{N})$ of mangroves and lichens in an oligotrophic, microbiallyinfluenced ecosystem. Biogeosciences 5, 1693-1704.

Fournier, N., Dore, A.J., Vieno, M., Weston, K.J., Dragosits, U., Sutton, M.A., 2004 Modelling the deposition of atmospheric oxidised nitrogen and sulphur to the United Kingdom using a multi-layer long-range transport model. Atmos. Environ. 38, 683-694.

Felix, J.D., Elliott, E.M., 2014. Isotopic composition of passively collected nitrogen dioxide emissions: vehicle, soil and livestock source signatures. Atmos. Environ. 92, 359-366.

Fowler, D., Coyle, M., Skiba, U., Sutton, M.A., Cape, J.N., Reis, S., Sheppard, L.J., Jenkins, A., Grizzetti, B., Galloway, J.N., Vitousek, P., Leach, A., Bouwman, A.F., Butterbach-Bahl, K., Dentener, F., Stevenson, D., Amann, M., Voss, M., 2013. The global nitrogen cycle in the twenty-first century. Philosophical Trans. R. Soc. BBiological Sci. 368.

Gaio-Oliveira, G., Branquinho, C., Maguas, C., Martins-Loucao, M.A., 2001. The concentration of nitrogen in nitrophilous and non-nitrophilous lichen species. 
Symbiosis 31, 187-199.

Gaio-Oliveira, G., Dahlman, L., Palmqvist, K., Maguas, C., 2005. Responses of the lichen Xanthoria parietina (L.) Th. Fr. to varying thallus nitrogen concentrations. Lichenologist 37, 171-179.

Giordani, P., 2007. Is the diversity of epiphytic lichens a reliable indicator of air pollution? A case study from Italy. Environ. Pollut. 146, 317-323.

Goovaerts, P., 1997. Kriging vs stochastic simulation for risk analysis in soil contamination. In: oares, A., Gomez-Hernandez, J., Froidevaux, R. (Eds.), geoENV I - Geostatistics for Environmental Applications. Kluwer Academic Publishers, Dordrecht, pp. 247-258.

Hellmann, C., Werner, C., Oldeland, J., 2016. A spatially explicit dual-isotope approach to map regions of plant-plant interaction after exotic plant invasion. PloS One 11 e 0159403.

Hertel, O., Skjoth, C.A., Reis, S., Bleeker, A., Harrison, R.M., Cape, J.N., Fowler, D., Skiba, U., Simpson, D., Jickells, T., Kulmala, M., Gyldenkaerne, S., Sorensen, L.L. Erisman, J.W., Sutton, M.A., 2012. Governing processes for reactive nitrogen compounds in the European atmosphere. Biogeosciences 9, 4921-4954.

Hijmans, R.J., Cameron, S.E., Parra, J.L., Jones, P.G., Jarvis, A., 2005. Very high resolution interpolated climate surfaces for global land areas. Int. J. Climatol. 25, 1965-1978.

Il Lee, Y., Lim, H.S., Il Yoon, H., 2009. Carbon and nitrogen isotope composition of vegetation on King George Island, maritime Antarctic. Polar Biol. 32, 1607-1615.

INE, 2011. Instituto Nacional de Estatística (Portuguese Statistics Institute), Censos 2010.

Laffray, X., Rose, C., Garrec, J.P., 2010. Biomonitoring of traffic-related nitrogen oxides in the Maurienne valley (Savoie, France), using purple moor grass growth parameters and leaf (15)N/(14)N ratio. Environ. Pollut. 158, 1652-1660.

Lin, C.T., Jickells, T.D., Baker, A.R., Marca, A., Johnson, M.T., 2016. Aerosol isotopic ammonium signatures over the remote Atlantic Ocean. Atmos. Environ. 133, 165-169.

Liu, X.Y., Xiao, H.Y., Liu, C.Q., Li, Y.Y., Xiao, H.W., 2008. Stable carbon and nitrogen isotopes of the moss Haplocladium microphyllum in an urban and a background area (SW China): the role of environmental conditions and atmospheric nitrogen deposition. Atmos. Environ. 42, 5413-5423.

Olsen, H.B., Berthelsen, K., Andersen, H.V., Sochting, U., 2010. Xanthoria parietina as a monitor of ground-level ambient ammonia concentrations. Environ. Pollut 158, 455-461.

Phillips, D.L., Gregg, J.W., 2003. Source partitioning using stable isotopes: coping with too many sources. Oecologia 136, 261-269.

Pinho, P., Augusto, S., Branquinho, C., Bio, A., Pereira, M., Soares, A., Catarino, F., 2004. Mapping lichen diversity as a first step for air quality assessment. J. Atmos. Chem. 49, 377-389.

Pinho, P., Augusto, S., Maguas, C., Pereira, M.J., Soares, A., Branquinho, C., 2008a. Impact of neighbourhood land-cover in epiphytic lichen diversity: analysis of multiple factors working at different spatial scales. Environ. Pollut. 151 414-422.

Pinho, P., Augusto, S., Martins-Loucao, M.A., Pereira, M.J., Soares, A., Maguas, C. Branquinho, C., 2008b. Causes of change in nitrophytic and oligotrophic lichen species in a Mediterranean climate: impact of land cover and atmospheric pollutants. Environ. Pollut. 154, 380-389.

Pinho, P., Dias, T., Cruz, C., Tang, Y.S., Sutton, M.A., Martins-Loucao, M.A., Maguas, C. Branquinho, C., 2011. Using lichen functional diversity to assess the effects of atmospheric ammonia in Mediterranean woodlands. J. Appl. Ecol. 48, 1107-1116.

Pinho, P., Llop, E., Ribeiro, M.C., Cruz, C., Soares, A., Pereira, M.J., Branquinho, C. 2014a. Tools for determining critical levels of atmospheric ammonia under the influence of multiple disturbances. Environ. Pollut. 188, 88-93.

Pinho, P., Martins-Loução, M.A., Máguas, C., Branquinho, C., 2014b. Calibrating tota nitrogen concentration in lichens with reduced nitrogen emissions at regiona scale. In: Sutton, M., Mason, K., Sheppard, L., Sverdrup, H., Haeuber, R., Hicks, W. (Eds.), Nitrogen Deposition, Critical Loads and Biodiversity. Springer pp. 217-227.

Preston, T., Owens, N.J.P., 1983. Interfacing an automatic elemental analyser with an isotope ratio mass-spectometer - the potential for fully automated total nitrogen and N-15 analysis. Analyst 108, 971-977.

Ribeiro, M.C., Pinho, P., Llop, E., Branquinho, C., Soares, A., Pereira, M.J., 2014. Associations between outdoor air quality and birth weight: a geostatistical sequential simulation approach in Coastal Alentejo, Portugal. Stoch. Environ. Res. Risk Assess. 28, 527-540.

Statsoft, 2012. Statistica v.10.

Sutton, M.A., Milford, C., Dragosits, U., Place, C.J., Singles, R.J., Smith, R.L, Pitcairn, C.E.R., Fowler, D., Hill, J., ApSimon, H.M., Ross, C., Hill, R., Jarvis, S.C. Pain, B.F., Phillips, V.C., Harrison, R., Moss, D., Webb, J., Espenhahn, S.E., Lee, D.S. Hornung, M., Ullyett, J., Bull, K.R., Emmett, B.A., Lowe, J., Wyers, G.P., 1998 Dispersion, deposition and impacts of atmospheric ammonia: quantifying local budgets and spatial variability. Environ. Pollut. 102, 349-361.

Varela, Z., Carballeira, A., Fernandez, J.A., Aboal, J.R., 2013. On the use of epigaeic mosses to biomonitor atmospheric deposition of nitrogen. Archives Environ. Contam. Toxicol. 64, 562-572.

van den Berg, L.J.L., Jones, L., Sheppard, L.J., Smart, S.M., Bobbink, R., Dise, N.B. Ashmore, M.R., 2016. Evidence for differential effects of reduced and oxidised nitrogen deposition on vegetation independent of nitrogen load. Environ. Pollut. 208, 890-897.

Zechmeister, H.G., Richter, A., Smidt, S., Hohenwallner, D., Roder, I., Maringer, S. Wanek, W., 2008. Total nitrogen content and delta(15)N signatures in moss tissue: indicative value for nitrogen deposition patterns and source allocation on a nationwide scale. Environ. Sci. Technol. 42, 8661-8667. 